\title{
Visual representation of COVID-19 in Children's Literature: A Semiotic Analysis
}

\author{
* Huda Tufail, MPhil Scholar \\ ** Dr. Mamona Yasmin Khan (Corresponding Author) \\ *** Prof. Dr. Uzma Qureshi, Vice Chancellor
}

\begin{abstract}
The massive spread of Coronavirus has badly affected the entire globe and lives of the people irrespective of age or gender. Children in this regard are no exemption. They are affected not only physically but also emotionally and mentally due to the virus and quarantine period. This study aims to provide a semiotic analysis of the visual representations of Covid-19 in the children's book covers selected on a global level. These covers are new emerging literature and serve to narrate a global discourse related to COVID-19. The researchers have followed the qualitative approach and the data have been collected using purposive sampling technique to provide a holistic interpretation of the selected covers. Framework, selected for the study, is 'Semiotic Analysis' by Kress and van Leeuwen (2006). The findings revealed that the participants' actions and overall circumstances in these covers are highly meaningful. The action narrative and colorful illustrations aim to motivate the young audience in a positive manner. Furthermore, they communicate a message of hope and urge them to fight against the virus. The visuals in these covers are therefore quite significant in their meanings and interpretations.
\end{abstract}

Keywords: Covid-19, Books Cover, Semiotic Analys is, Visual Representations, Children

Introduction

Children literature has a long history and plays an important role in the lives of young children as it provides them new avenues of learning and experiences (Trepanier-Street \& Romatowski, 1999; Tsao, 2008;). Picture books are especially integral in this regard as they present not only text but visuals illustrations as well. As young children are new to the outside world, picturebooks can also build the ir social and cultural perspectives and integrate different ideologies for them (Nodelman, as cited in Hunt, 1996). The incorporation of the visuals together with the text can boast creativity and provide more understanding of the stories. According to Painter, Martin and Unsworth (2013), in picturebooks, the relation of verbal resources with the visual choices provide deeper meanings and understanding of the story (p. 2) Visuals in the picture books are therefore, essential in understanding the social information and cultural meanings embedded in them. Moreover, they are based on the signs and clues which have some hidden motivation or purpose.

COVID-19 pandemic has encompassed the whole globe and has left deep effects on all the fields of life. In the field of education, there is a continuous and ongoing process of research done in different perspectives. Impact of this pandemic on children is one of the most important field as they are quite susceptible when it comes to the side effects of this 'more than a year' stay at home. Children books can play immense role in helping these children emotionally and educate them about the pandemic in a friendly way. This semiotic study of children books' covers has mainly addressed the visual representation of the COVID-19 pandemic. The visual clues and strategies employed by the illustrators might prove helpful in different disciplines and various authorities.

\section{Researh Problem}

Children literature is an important genere as it is being focused in the field of research on different gounds. Visuals can have significant impact on the young minds due to which the children books illustrations are indispensble in semiotic studies. How does the visual analysis of the covers of children books written during COVID-19 pandemic, offers/provides new and significant insights

\footnotetext{
* Department of English, The Women University Multan, Punjab, Pakistan Email: hudatufail99@ gmail.com

** Department of English, The Women University Multan, Punjab, Pakistan

Email: mamonakhan1234@gmail.com

*** The Women University Multan, Punjab, Pakistan Email: uzmaquraishi@yahoo.com
} 
about impact of the worldwide phenomenon on perceptions of readers and young children,. The present study is an attempt to fill this gap.

\section{Research Questions}

The researh questions for the present study are as given below:

1. What type of visual discourse is represented in the children book covers in the perspective of Covid-19?

2. What is the perceived impact of the visuals employed in the covers on the young children?

\section{Lite rature Review}

Study of viusal clues in children books is quite significant due to the social and cultural values present in them. Children books are a unique resource of learning especially for young children. Hasen \& Zambo (2005) have assured that picture books as an important tool for cognitive, social and physical development of young children as they help them comprehend new theories and concepts to enhance their learning. In another study of Cadwell, Falcus \& Sako, (2021) it is proposed that the role of metaphorical language regarding cognitive and mental issues like dementia needs to be addressed properly as they can help shape the better understading of the children and their relation with their family members. Moreover, the multimodal texts in picture books can improve the English and foreing language acquisition (Mourão, 2009, chung, 2006)

Book coves are an important visual resource as they provide meaningful information in the perspective of marketization and various other fields of research. Rollins, (2014) in his study has found out that in today's enviornement of e-commerce, book covers have still more importance in the case of e-books as they set the standards for preferences of the buyers and thus impact the marketization of books, as a whole. . Many significant researches have indicated the immense need to examine the visuals of the covers in different genres like adults novels, fiction books, religious books and magazine etc. (O’Conelle, 2010, Gallagher, 2015, Lamb, 2016, Viljoen \& Koenig-Visagie, 2011).

Salman \& Eghtesadi, (2015) have applied an intersemiotic approach on four book covers of classic novels one of English and the other three of Persian translation. Through the research corpus they have analyzed the ideological and social implications. For this reason, the theory they have used is 'Semiotic Analysis' of Kress and van Leeuwen (2006). They have focused on the graphic design of the book covers and the embedded ideological influences in the translated versions. Barathi \& Babu, (2019) through their semiotic analysis of various book covers of a sci-fiction by Mary Shelly labeeled as Frankestin have come to this point that language and viusal representaitons as a combined whole have powerful impact on the choice of readers or viewers. They have concluded that iconographpy is an idespensible element in the creation of a cover as it makes it more demanding and attractive.

Hiippala, (2007) did a multi-semiotic analys is of brochures for tourism by employing the SFL theory of Halliday $(1978,1994)$ to study the content and the modes of text and image together through Stockl, (2004). The researchers have tried to find out the relationship between verbal and visual content through Hallidian metafunctions and the relation of modes and sub-modes through Stöckl, (2004). Furthermore, the multimodality of the brochures has also been understood through the analysis of colours, composition and typography present in them. Stoian, (2015) in the research, "Analysing Images: A Social Semiotic Perspective" has done a semiotic analysis of a honeymoon advertisement from a tourist website. She has employed the theory of Grammar of visual design by Kress and van Leeuwen (1996/2006) and has analyzed the three metafunctions of visual communication. Through a qualitative research, she has concluded that the visual study of pictures can be very helpful not only in the understanding of their apparent meanings but also in the interpretation of the hidden purposes behind these images.

Singh, (2015) in his thesis has investigated the interpersonal meanings present in the cover stories of different mobile phones through a multimodal analys is. The major aim of the study is to analysis linguistic and visual elements in the cover stories. Two theories have been exploited in this regard i.e. firstly, the transitivity system by Halliday (2004) and secondly, the visual study of narrative $\&$ conceptual representations by Kress \& van Leeuwen (2006). The conclus ions have revealed that the ads of cell phones are highly meaningful and evocative as the linguistic and visual analys is have shown that they are designed to attract the buyers and consumers. These studies indicate the significance of visual analys is of covers in different genres and in various perspectives. Furthermore, no study so far has been conducted on the covers of children books to highlight the phenomenon of COVID-19 and this study intends to fill this gap. 


\section{Frame work}

Semiology is initially the study of signs and symbols which was proposed by the two most eminent personalities in the field of linguistics, Saussure and Peirce in the beginning of the twentieth century. Various other scholars and practitioners have elaborated the sign system in different ways. In this regard, Eco (1979) has defined sign "as everything which can be taken as significantly substituting for something else" (p. 7). Signs are therefore resources for meaning-making and depend on the perspective or context of its user and interpreter.

In their seminal work known as "Social Semiotics", Hodge and Kress (1988) have considered language as a resource for meaning making in the social and cultural perspectives. (Gualberto \& Kress, 2018). These concepts are discussed and represented in different fields of language and provided broader insights for the study of multimodality (ibid). Halliday (1985) has also emphasized on the social and contextual meanings and functions embedded in our language system which is further integrated in the work of Kress and van Leeuwen (1996/2006) in the ir work, Reading Images: The Grammar of Visual Design. This work provides a detailed understanding of the visuals and images through the integration of the Halladian metafunctions of language, ideational, Interpersonal and textual. They have highlighted Halliday's notion that 'grammar is more than a set of rules and it can be interpret human experiences and narrate a mental image of the ir reality in the outside world' (Halliday, 1985 p. 101).

Images have similar grammar and they are similar to the textual components in providing new interpretations of the social and contextual experiences (Kress and Leeuwen, 2006 p. 2). They have proposed three systems of categorization to interpret the visuals in a systematic way and therefore, interpret the signs and clues embedded in them.

\section{Representation}

Representational processes are similar to transitivity system as they also interpret the experiences of the outside world through different participants. It has mainly two types; narrative and conceptual. The former highlight the action, participants, events and circumstances and the later highlight the symbolic, analytical or class system present in the visuals.

\section{Interactional Representations}

They are based on the notion of interaction between the participants through different perspectives of gaze, social distance, angle and modality etc.

\section{Composition}

It is the third aspect of visual grammar and explains the embedded information in the layout and highlight the salient features and discuss the framing quality in the images.

In the analytical framework for the present study the researchers have adapted the framework of Kress and van Leeuwen (2006). These aspects are specifically selected in the study to analyze the children book covers:

$\begin{array}{ll}\text { 1. } & \text { Representation } \\ \text { 2. } & \text { Modality Marker } \\ \text { 3. } & \text { Composition }\end{array}$

\section{Methodology}

In this study, qualitative approach of research has been employed. In order to select books, purposive technique is used in view of the nature of the research. The selection is based on the notion that more focused approach will generate better understanding about a particular situation of pandemic. The covers selected for the study fulfill the demand of the visual analysis. The data is collected from the websites as all of these are e-books and published online, hence easily accessed. Semiotic analysis is selected for this research because of the illustration and visual representations of the covers and also because of the uniqueness of the phenomenon of COVID-19 in children literature.

\section{Data Analysis}

All the globally selected children book covers have been analyzed through the qualitative approach for the visual analysis, the framework of Kress and Van Leeuwen (2006) is employed to find out how COVID-19 has been represented in these covers and the communicative purposes embedded in them. For the more critical and credible analysis, the researcher has used her subjectivity together with the insights from the analytical framework for this study. The semiotic analysis of these covers has been given below: 


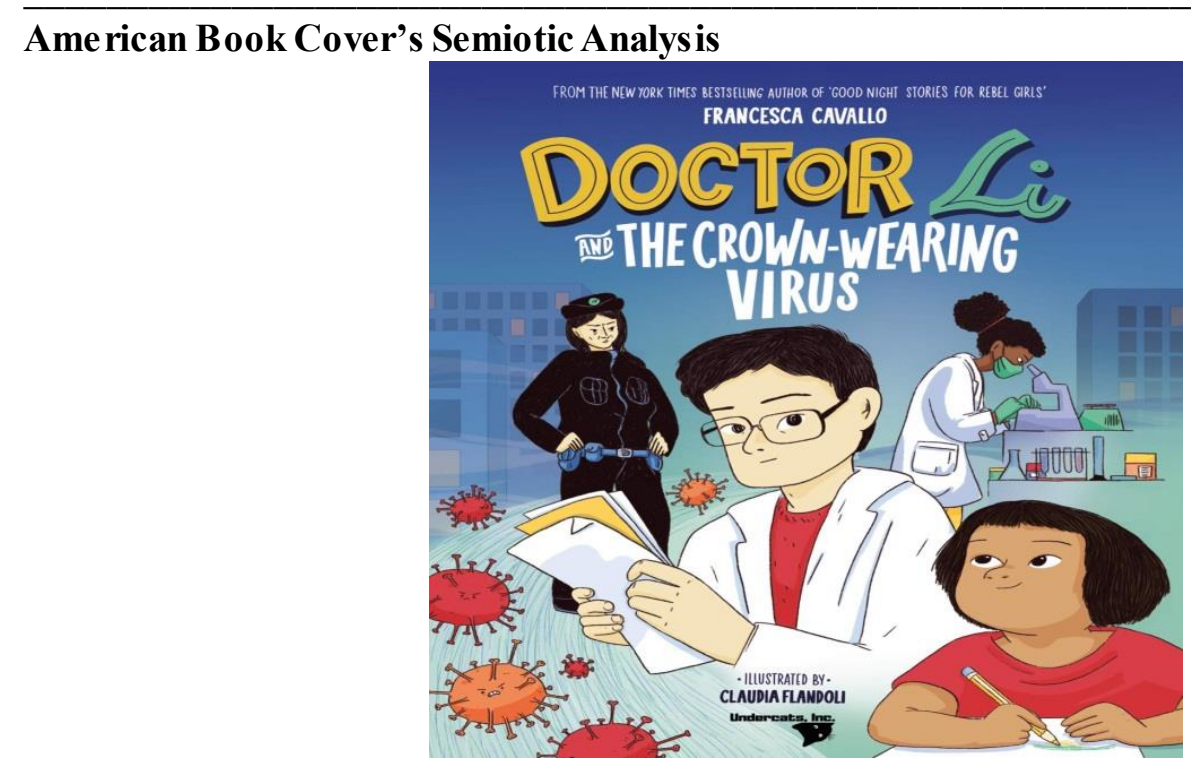

\section{Representations}

Figure: 1.1.

\section{Narrative Processes}

In representations, there are two types of processes; narrative and conceptual. Narrative processes represent actions which form vectors of some kind. Vectors represent the fact that someone is 'doing something' (Kress \& Leeuwen, 2006 p.63). The person who perform the action is termed as 'actor' and he is defined as someone who is forming the vector or from whom the vector can be employed on others. (ibid, p. 59) In the figure, 1.1., there are four participants; a doctor at the center, a girl at the front ant a cop and scientist in the background. The doctor is looking at the viewers and his eyes are creating vectors with them which indicates that he is interacting with them through his eyes and smile. $\mathrm{He}$ is also holding some papers in his hands which show that he is busy in some work. The girl is looking at the doctor and her role in the image is of the reactor. According to Kress and Leeuwen (2006) "When the vector is formed by an eyeline, by the direction of the glance of one or more of the represented participants, the process is reactional." (p.67) Here her smiling face is providing a view that she approves the doctor's work and admire him for his bravery and courage. Moreover, the cope in the back is looking somewhere with suspicious eyes which indicate the tension which has prevailed in the COVID-19 scenario. The scientist is busy in examining the viruses as her hands and eyes are creating vectors with the microscope and her goal here seems to be the research on the coronavirus.

\section{Conce ptual Processes}

In conceptual processes, the represented participants are understood "in terms of class, or structure or meaning." (ibid, p. 79) They are based on classificational, analytical and symbolic processes. In classificational ones, the relation of the participants is highlighted through the overt and covert taxonomies. In the figure, 1.1, covert taxonomy is present as the viruses can be considered 'subordinates' because of their size and placement at the corner of the page and the doctor and other three participants are 'superordinates' because of their immense size and active role. In the cover, symbolic meanings can be inferred from the representation of the male and female gender in which women are larger in number and they are performing most of the actions like investigating, experimenting and writing. Moreover, the colour differences are also absent in it. It indicates that people all over the world are united in this pandemic without any difference of colour or gender.

\section{Modality Marker}

Modality in language ensures the reliability of a statement. In semiotics, the truth value of any visual or text is based on the society it belongs. (ibid, p. 154) Therefore, the visuals are considered credible when they are nearer to the reality of the viewer and possess such signs and clues that enhances their natural look.

\section{Colour saturation/modulation and differentiation}

Colours are highly valuable in the visual studies as they possess certain meanings in them. In the figure, 1.1, there are different colours that have been employed by the illustrator. As for the 
saturation-scale, the colours are highly saturated which indicates that the message they are conveying to the children is of being active and positive during the pandemic.

\section{Contextualization}

The background of a visual is essential in the depiction of a context. In this cover, the background is present but not quite clear. There are two buildings in the image and they are represented by the participants standing before them. On the left, the cop is representing the police station and on the right, the scientist is representing a laboratory or hospital. Though the background is not very clear but it is providing a realistic idea about the institutions that are busy day and night to fight COVID-19.

\section{Representation}

The visuals in the figure 1.1, are quite clear in detail. All the participants and the ir equipments or tools are visible and shaded in appropriate way. Therefore, the children can easily identify the characters' profession or activities in which they are indulged. Moreover, their facial expressions are also presenting significant information about their role in the image.

\section{Composition}

Compositional elements are necessary to highlight the layout and configuration of different aspects in a visual. They are the integration of both metafunctions of ideational and interpersonal one and provide an interrelated system of information value, salience and framing.

\section{Information Value}

It is related to the zones of a visual and the placement of the information in different parts provide different interpretations. In the figure, 1.1, the doctor is at the center and the other participants at the margins of the cover. The center presents the most crucial information regarding to which other elements at the margins are relatively subservient. (ibid, p. 196). Elements in the margins are therefore subordinate and dependent on the center. The doctor is the main participant as the whole story revolves around him. Furthermore, the cover can also be divided into top and bottom parts. Top is labelled as 'Ideal' and the bottom is termed as 'Real'. (ibid, p.187) In the figure, 1.1., the title or the textual information is the 'Ideal' and the image is 'Real.' According to Kress and Leeuwen (2006) in such cases, language plays a leading role and represents ideology whereas visual has a submissive part in this regard. (ibid)

\section{Salience}

Salience promotes a sense of prominence in the visual aspects. It is achieved through different ways like size, colour combination, placement or perspective. (ibid, p. 202). In the figure, 1.1, Doctor Li has the most prominent and foregrounded presentation as he is at the center and enormous in size as compared to the other characters. Moreover, he is also providing a tonal contrast with the light background and thus can be considered the most salient character.

\section{Framing}

In semiotics, visual framing is important in the sense that it promotes connectedness among the participants. This can be realized through lines, spacing or colours etc. In this figure, the participants in the image are not respected in some outline or frame. As "The absence of framing stresses group identity, its presence signifies individuality and differentiation." (ibid, p. 203) the participants are showing their struggles at the individual level.

\section{African Book Cover's Semiotic Analysis.}

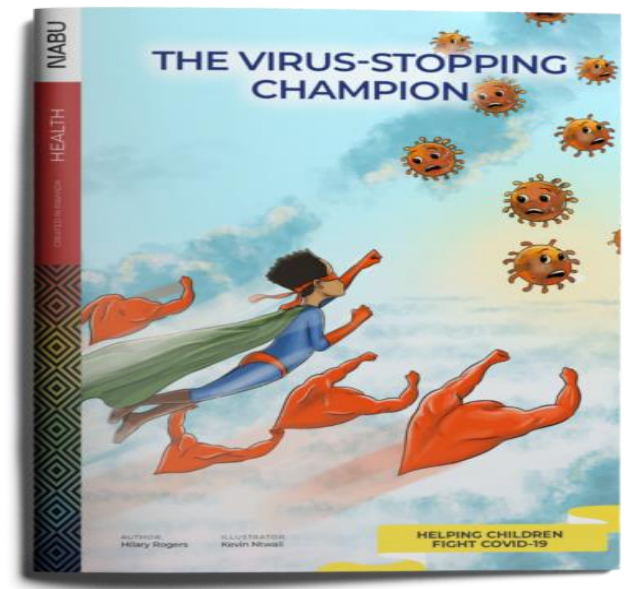

Figure: 1.2 . 


\section{Representations \\ Narrative Processes}

The Virus-Stopping Champion is an African children book which narrates the story of a boy who is fed up with the lockdown and wants to fight the virus himself. In the figure, 1.2, there are three participants, the boy himself, hearts that are fighting with him and the viruses. The boy and his friend hearts which are animate in this book cover are flying towards the corona viruses. Their hands are creating vectors with the viruses and indicating that they are in action. (Kress and Leeuwen, p.59). The viruses, on the other hand, are looking at the boy and his army and their worried faces are expressing their fear from them as they are the 'goal' or target of the boy and due to the actor and target it is a transactional process (ibid, p. 50) The circumstances in this processes are the clouds and bright sky which are revealing the natural scenery. Through such an image, the illustrator and writer are trying to urge the young audience to take action against this corona virus as it is not something to be worried about, by using imagery of a superhero having exceptional powers to fight with the virus.

\section{Conce ptual Processes}

These processes informs the classes and systems of the represented participants. In the figure, 1.2, the participants can be divided into two parts on the base of their placement or symmetry; left and right. In the cover, covert taxonomy is apparent in which the different level of the participants is imparting significant meanings. Though the boy is at the lower level but he is positioned upwards and this presents him to be the superordinate. Whereas the corona viruses are at the top but they are moving backwards and away from the center due to which they can be termed as subordinates in this image.

Clouds are providing symbolic interpretations as they are suggesting the imaginary world of the child because it is not a real world in which he can fight the virus through hands. The refore, the illustrator is trying to boast the children's imagination and urging them to become strong and fight the coronavirus.

\section{Modality Markers}

\section{Colour saturation/modulation and diffe rentiation}

Colours possess their own grammar and provide meaningful interpretations on their own due to it in different situations, Kandinsky $(1977,1944)$. Therefore, colours are a useful resource for meaningmaking through signs and it is mainly based on the way people use or interpret them. (Kress and Leeuwen, 2006 p. 230). In the figure, 1.2, different colours are present. In the background, quite low saturated colours have been employed like different shades of blue. Such colours enhance a clam and tender impact on the viewers. (ibid, p. 233) The colours of the representatives, however, are more saturated which are providing exuberant and adventurous impact. Moreover, the blue colour is modulated in this cover as it is indicating the impact of sunlight on the clouds which indicates that it is day time. These colour details are promoting a naturalistic appearance in the cover.

\section{Contextualization}

The contextual detail of any image enhances modality in the visuals. In this cover, the background of the main participants is highly contextualized. The clouds and sunlight are providing a natural view in this figure.

\section{Representation}

In this children book cover, the participants are vividly portrayed. The background, colours and narrative and every aspect which could improve the quality of the pictorial detail has been presented in the cover. The colours are moderately employed and the facial expressions of the viruses are narrating the story themselves.

\section{Composition}

Information Value

Information value is related to the information placed in the sections or zones of a page or image i.e. left/right, top/bottom and center/margin. (ibid, p.177). The figure 1.2, is divided into left and right sections where left is termed after Halliday as 'Given' and the right is 'New'. Given is considered old information 'which is already known' and new provides a new perspective about it. (ibid, p. 181) In this cover, the child and his army is on the left which indicates that children are ready to fight the virus but the new perspective which is shared here is that the viruses are also afraid of the brave and strong children. 


\section{Salience}

In visuals, to convey a message or promote certain information, specific aspects are made more prominent than others. It enhances their visual weight and make them eye-catching for the viewers. In this figure, 1.2, the child and his army are larger in size and the colours employed for them highly saturated which is providing a tonal contrast with the light background. These features are making them the most prominent aspects of this cover.

\section{Framing}

Compositional elements include framing as a key element because it presents the connectivity of the representations with each other. In this figure, the boy and his army of hearts are separated with the corona viruses through a visible space in between them. It is promoting a sense of unity on the part of the child and he is conveying a message to his young viewers that COVID-19 scenario demands strength and unity among the people especially children. Therefore, they need not to be afraid of it at all.

\section{Results and Conclusion}

Book covers play immense role in attracting the buyers and enhancing the marketization (Darling, 2019). Their typography, illustrations and representation of various aspects are immensely important in increasing the need for visual analysis. Book covers are generally replete with visuals as they are supposed to attract young readers and fulfill the need of their entertainment and literacy therefore. In the perspective of COVID-19 scenario, children's vulnerability and sensitivity could be better addressed in the children books as everyone is stuck at home and children need books to fulfill the gap of school, teachers and friends.

The visual analysis of the covers of these book covers has revealed important information regarding the ir representations and their perceived impact. Action narratives of these covers have highlighted the type of actions, participants, vectors and circumstances presented in them. All of the covers contain actions of some sort which in terms can trigger young children to do the same. Fighting the virus is the common theme in these covers as the virus has spread in the whole world and people of every age are its victim. Participants in these covers, therefore, comprise mainly of young children who are either fighting the virus or adore the heroes who are fighting it. In either case, positive message is conveyed. The notion of super heroes has been presented in these figures $(1.1 . \&$ 1.2) which is symbolically important as it can create a sense of motivation and inspiration in the young readers who get fascinated by the fictional characters of super human powers. O'Handley, Radley and Cavell (2016) in their study have also investigated a similar case in which they have concluded that when children are exposed to content which contains superheroes in an educational environment, it can have positive impact on them. (as cited in K. Zeytuncu, 2019)

The markers of modality in both covers are enhancing the naturalistic quality of the background. As for the representations, the visual details are aptly employed in them to give a realistic impression to the young audience who can clearly relate them with their own contexts. In these covers the illustrators have employed various colours to avoid monotonous impact of COVID19 , rather a more attractive and adventurous image is portrayed. Colours are moderately saturated and modulated in the covers which might have a tender and soothing effect on the young minds (Kress \& Leeuwen, 2006, p. 233). The visual analys is of the compositional elements in the covers can enhance the understanding of the layout, salience and framing and the way they are ordered to achieve meaningful interpretations about the coronavirus represented in them.

The children book covers in this study comprised of colourful illustrations and active characters which can impact the psychology of young minds and make them more happy and energetic and save them from psychological traumas and mental health issues. This view is supported by the study of Aditia and Noviyanti (2019). The study can be concluded with this view of Nodelman, (1999) that it is necessary to enhance the understanding of the visuals in children books for both children and their elders as it "will allow us to give them the power to negotiate their own subjectivities - surely a more desirable goal than repressing them into conformity to our own view." (p.80)

\section{References}

Aditia, P. \& Noviyanti, R. (2019) Visual Analysis Of Children Books Illustration As a Psychiatric Therapy. 6th Bandung Creative Movement International Conference in Creative Industries. Retrieved from: https://media.neliti.co m/media/publications/293366-visual-analys is -of-children -books-illust8a7ea093.pdf. 
Barathi, S., \& Babu, M.I. (2019) Semiotic analys is of the selected book covers of Mary Shelly's 'Frankenstein'. Literary Endeavour.Vol. X: Issue: 2 ISSN 0976-299X.

Caldwell, E. F., Falcus, S. \& Sako, K. (2021) Depicting Dementia: Representations of Cognitive Health and Illness in Ten Picturebooks for Children. Children's Literature in Education 52:106-131 https://doi.org/10.1007/s 10583-020-09405-w

Chung, Y. L. (2006) Recognizing the Narrative Art of a Picture Book: Word-and-Image interactions in Anthony Browne's Gorilla. Journal of Taipei Municipal University of Education, 37 (1).

Darling, S. (2019). How are book covers and their components represented in the digital market? Interscript Journal, 2, 20-35. http:// doi.org/ 10.14324/111.444.2398-4732.004

Eco, U. (1979). A theory of semiotics. Bloomington: Indiana University Press

Gallangher, D. P. (2015).The look of fiction: A visual analysis of the front covers of the New York Times bestsellers. (Master's Thesis) Rochester Institute of Technology. https://scholarworks. rit.edu/theses

Gualberto, C. \& Kress, G. (forthcoming, 2018) 'Social Semiotics', chapter in the International Encyclopedia of Media Literacy, edited by Renee Hobbs and Paul Mihailidis, NY: Wiley-Blackwell

Halliday, M.A.K. (1985) An Introduction to Functional Grammar, London, Edward Arnold.

Hansen, C.C. \& Zambo, D. (2005) Piaget, Meet Lilly: Understanding Child Development through Picture Book Characters. Early Childhood Education Journal, 33 (1). DOI: 10.1007/s 10643-005-0020-8

Hiippala, T. (2007). Helsinki: A Multisemiotic Analysis of Tourist Brochures. Retrieved from: https://www.se manticscholar.org/paper/Helsinki\%3A-A-Multise miotic-Analysis-of-TouristHiippala/a7e4f620406665f5971e6f55e3c664112c69b93a

Hodge, R., \& Kress, G. (1988). Social Semiotics. Cambridge, United Kingdom: Polity Press.

K. Z. (2019) A Literature Review on the Effects of Superheroes on Children. J Fam Med.; 6(6): 1184 ISSN : 2380-0658

Kandinksy, W. (1977 [1914]) Concerning the Spiritual in Art, New York, Dover Publications.

Kress, G. and van Leeuwen, T. (2006). Reading Images: The Grammar of Visual Design. (2nd Edition) London: Routledge.

Lamb, C. (2016). Men in Vogue: A Visual Analysis of the Male Gender on American Vogue Covers. (Master's Thesis). Rochester Institute of Technology.

Mourão, S. (2009) "Surprised!" Telling the pictures. Can the illustrations in picture books promote language acquisition? Saber \& Educar DOI: 10.17346/se.vol14.143

Mudiyanselage, K. (2016). The role of picture books in developing an empathic response towards cultural difference (Doctoral dissertation, Queensland University of Technology).

Nodelman, P. (1999) Decoding the lmages: lllustration and Picture Books. Hunt, P. (ed.) Understanding children's literature: Key essays from the International Companion Encyclopedia of Children's Literature. London: Routledge.

O’Connell, K.C. (2010) Young Adult Book Cover Analysis (Master's Thesis). University of North Carolina, Wilmington. Retrieved from: http://dl.uncw.edu/Etd/2010-1/oconnellk/ kathleenoc-onnell.pdf.

O'Handley, R. D., Radley, K. C., \& Cavell, H. J. (2016). Utilization of superheroes social skills to reduce disruptive and aggressive behavior. Preventing School Failure: Alternative Education for Children and Youth, 60(2), 124-132.

Painter, C.; Martin, J. R.; Unsworth, L. (2013) Reading Visual Narratives. London: Equinox.

Rollins, H. (2014). A conjoint analysis of the value of book covers in e-book buying decisions. (Thesis) Rochester Institute of Technology. https://s cholarworks .rit.edu/theses/8600/.

Salmani, B.\& Eghtesadi, Z. (2015) An Intersemiotic Approach towards Translation of Cover Designs in Retranslated Classic Novels. Theory and Practice in Language Studies, Vol. 5, No. 6, pp. 1185-119. DOI: http://dx.doi.org/10.17507/tpls.0506.09

Singh, S.K. (2015) A Multimodal Analysis Of Cover Stories On Mobile Phones: An Ideational Perspective. Retrieved from: http://studentsrepo.um.edu.my/5483/1/Salveen_Kaur_Gill__(TGB100052)__Final_Research_Report_2015.pdf. (Master's Thesis)

Stoian, C. E. (2015) Analysing Images: A Social Semiotic Perspective. Scientific Bulletin of the Politehnica University of Timişoara Transactions on Modern Languages Vol. 14, No. 1. Retrieved from: https://www.researchgate.net/publication/307476982_Analysing_Images_A_Social_Semiotic_Perspect ive

Trepanier-Street, M.L., \& Romatowski, J.A. (1999). The influence of children's literature on gender role perceptions: A reexamination. Early Childhood Education Journal, 26(3), 155-159.

Tsao, Y. (2008). Gender issues in young children's literature. Reading Improvement. Fall Issue.

Viljoen, S. \& Koenig-Visagie, L.H., (2011) Gender representation in Christian book covers: A case study, Verbum et Ecclesia 32(1), Art.\#487, 9 pages.doi:10.4102/ ve.v32i1.487 